\title{
Can Natural Law Thinking Be Made Credible in Our Contemporary Context?
}

One of the best-known members of the United Nations Commission which drafted the 1948 "Universal Declaration of Human Rights," Jacques Maritain, famously held that the "natural rights" or "human rights" possessed by every human being are grounded and justified by reference to the natural law. ${ }^{1}$ In many quarters today, the notion of the natural law, and arguments for a set of natural rights grounded in the natural law, have come under fierce attack. One common line of attack is illustrated by the arguments of some utilitarians, for whom "natural law thinking" is mistaken insofar as it implies that there is an absolute moral prohibition against violating any human being's "natural rights." Even if there is such a thing as "natural rights," these utilitarian argue, such rights - including even the natural "right to life" - are necessarily relational, and thus have meaning only within the context of a larger social whole. As a result, the argument goes, the supposed "natural rights" possessed by individual human beings are never inviolable or unconditional, but instead always negotiable and subject to being "traded away" for the sake of greater social utility. Consider just one alleged counter-example to the notion that there are inviolable or unconditional "natural rights": it is well-known that approximately 36,000 people in the United States die every year as a result of influenza infections or influenza-related complications. ${ }^{2}$ There is little doubt that hundreds, and probably even thousands, of human lives would be saved every year if local governments were to pass laws requiring flu vaccinations for all members of at-risk populations (e.g., the very young and the very elderly). It would seem that there would be broad support for mandated flu vaccinations no matter what the expense - if human lives would be saved and if the natural "right to life" is inviolable or unconditional. ${ }^{3}$ And yet no such life-saving laws

See, for example, Jacques Maritain, Man and the State, Chicago 1951, pp. 90-98.

This figure of roughly 36,000 deaths per year is provided by the Centers for Disease Control and Prevention. For more information. see: <http://www.cdc.gov/flu/key facts.htm>.

This is the kind of argument made by the utilitarian ethicist. Peter Singer. in his critique of Martha Nussbaum's "capabilities approach" to the question of rights or entitlements. Nussbaum's "capabilities approach" is not exactly the same as a "natural law approach" to the question of rights, but these two approaches share common ground insofar as they are both opposed to the utilitarian notion that rights are negotiable and sometimes ought to be "traded away" for the sake of greater social utility. According to Singer. Nussbaum's opposition to utilitarian sum-ranking or utilitarian trade-offs "appears to require that if a society has only one member below the minimum entitlement level, it should spend all its resources on bringing that member above the entitlement level before it spends anything at all on raising the welfare level of anyone else, no matter how big a difference the resources could make to eve- 
exist, apparently because citizens and legislatures believe that the social costs and inconveniences would be too great. According to the utilitarian position, this demonstrates - contrary to what Ronald Dworkin and others say about rights $^{4}$ - that rights do not trump utility, but in fact are quite regularly and reasonably trumped by utility. In light of such contemporary understandings and policies, can natural law thinking about natural rights be made credible? In what follows, I shall argue that utilitarian thinkers are correct to hold that rights are intrinsically relational; but they are wrong to conclude that the relational character of rights entails that "natural rights" are not inviolable or not unconditional. But before presenting the case for natural law thinking on this topic, it will be helpful first to achieve some further clarity regarding what precisely is meant by "natural law."

\section{Three Kinds of Natural Law Thinking}

The term "natural law" is used in many different contexts and for many different purposes. Not surprisingly, the term "natural law" has taken on many different meanings. For the purpose of the present investigation, I shall distinguish three different senses of the term; of course, the three-fold classification that I shall present is by no means intended to be exhaustive or authoritative for all purposes.

According to one sense of the term, "natural law" thinking is a kind of thinking that belongs to jurisprudence or theory of law. According to this sense of the term, a person who endorses "natural law thinking" is one who holds that the directives of a legal sovereign must meet at least some (perhaps minimal) moral requirements in order to be valid even as law. To be a "natural law thinker" in this sense is to reject the legal positivist's claim that there is no "necessary connection" between law and morality. The well-known AugustinianThomistic proposition that "unjust law is no law at all" is an expression of natural law thinking in this first sense of the term.

According to a second sense of the term, "natural law" thinking is a kind of thinking that belongs to moral or ethical theory. This second sense of the term

ryone else in society. That, surely, is an absurdity." Singer's full critique of Nussbaum is available online at: <http:/www.utilitarian.net/singer/by/20021113.htm>.

4 For more on Dworkin's position regarding rights as trumps, see Ronald Dworkin, Rights as Trumps, in: Theories of Rights, edited by Jeremy Waldron, Oxford 1984, pp. 153-168. See also Ronald Dworkin, Taking Rights Seriously, Cambridge (MA) 1977, especially chapters 4 and 7.

5 Regarding the proposition that laws, properly speaking, must be just, Aquinas quotes Augustine (from De Libero Arbitrio, Book I, Chapter 5): "Non videtur esse lex, quae justa non fuerit." See Thomas Aquinas, Summa theologica, I-II, Q. 96, a. 4, c. Literally translated, the statement reads: "That which will not have been just does not appear to be law." 
can be further divided into a broader sense and a more restricted sense. According to the broader sense, a person who endorses "natural law thinking" as a matter of moral theory is one who holds that judgments regarding what is morally permissible, morally impermissible, and morally obligatory, can be rationally assessed as genuinely right or wrong judgments (even if - in some circumstances - it may be difficult to make judgments that are clearly known to be the right ones). In accordance with this broader sense of the term, natural law thinking in moral theory stands opposed to all forms of moral relativism or subjectivism (including emotivism and conventionalism), and is compatible with a wide range of diverging ethical theories (including various forms of deontology, contractarianism, and utilitarianism). According to the more restricted sense of the term, a person who endorses "natural law thinking" as a matter of moral theory is one who holds that correct judgments regarding what is morally permissible, morally impermissible, and morally obligatory are shown to be correct precisely insofar as they can be justified by reference to the ends or goals that are perfective of beings (including human beings), given the kinds of nature that such beings possess. Natural law moral thinking in this more restricted sense is opposed to other kinds of "natural law" moral thinking (i.e., it is opposed to certain kinds of natural law moral thinking in the broader sense) insofar as these other kinds of moral thinking seek to explain or justify moral judgments not by reference to "nature," but by reference to autonomy, consent, preference-satisfaction, or some other ground. Natural law moral thinking in this more restricted sense can be further divided into two sub-species: (a) "naturalistic" natural law moral thinking (in the restricted sense), according to which judgments regarding what ought to be the case (i.e., judgments about "goods" or "values") are derivable from judgments about what is the case (i.e., judgments about "facts" or "states of affairs"); and (b) "non-naturalistic" natural law moral thinking (in the restricted sense), according to which judgments regarding what ought to be the case are not derivable from judgments about what is the case. The so-called "new natural law" thinking of Germain Grisez, John Finnis, Robert George, and others, is a subspecies of non-naturalistic natural law moral thinking (in its restricted sense).

Finally, according to a third sense of the term, "natural law" thinking is a kind of thinking that involves claims about what is distinctive about human beings and thus about what uniquely characterizes the nature or dignity that is properly attributed to human beings (in contrast with the nature or dignity that might be attributed to other kinds of beings, such as non-rational animals). Not surprisingly, natural law thinking in this third sense of the term is closely connected with theorizing about "natural rights" and/or "human rights." This third sense of the term is famously expressed by the Thomistic proposition that there is no "natural law" in non-rational animals, although there is "natural law" in human beings, since the natural law pertains to the way that human be- 
ings participate in God's eternal law in a "more excellent" way (that is, in a rational way) that is not open to non-rational creatures. ${ }^{6}$ According to this third sense of "natural law thinking," human beings - precisely insofar as they are rational beings - possess a nature that is different in kind, and not merely different in degree, from that possessed by other animals, and thus possess basic dignity or rights that other, non-rational creatures do not possess. Aquinas makes a similar point about the unique and "more excellent" nature of the human being when he observes that the human being, by virtue of being a rational animal, is able to move itself (or order itself) towards its ends, whereas other animals are moved or ordered towards their ends "only by an other.""

It should be noted, of course, that a person can endorse "natural law thinking" in one sense of the term, without necessarily endorsing "natural law thinking" in the other senses. For example, a person can be a natural law thinker in the second (broader) sense of the term, without necessarily being a natural law thinker in the third sense of the term. Thus Peter Singer, the wellknown utilitarian philosopher and defender of "animal rights," has argued that it is possible to make moral judgments that are genuinely right or wrong (in accordance with the second, broader sense of natural law thinking), but also holds (in opposition to the third sense of natural law thinking) that "all animals are equal" when it comes to what is owed to animals (whether rational or not) as a matter of basic justice or rights.

\section{The Meaning of Justice}

The present enquiry will focus on the question of "natural law thinking" in the third of the three senses of the term outlined above. Of course, even though the present focus will be on "natural law thinking" in the third sense of the term, it will not be possible to refrain altogether from making statements that pertain also to "natural law thinking" in the other two senses. But while the different senses of "natural law thinking" are inter-related in various ways, it remains important to be mindful of the distinctness of the different senses, in order to avoid conceptual confusion.

Before addressing the primary question before us (that is, the question of whether talk of natural law and thus of natural rights, in accordance with the third sense of the term, can be made credible in our contemporary context), it will help to achieve some further clarity regarding what precisely is meant by the notion of rights. The notion of rights that I wish to articulate - and to defend, to the extent that such is possible within the confines of the present

See Thomas Aquinas, Summa theologica, I-II, Q. 91, a. 2.

See Thomas Aquinas, Summa theologica, I-II, Q. 1, a. 2, c. 
endeavor - is the notion that has its roots the Aristotelian-Thomistic tradition. I refer to the Aristotelian-Thomistic tradition, and not to Aristotle's own thought or to Aquinas's own thought, since it is an open question whether Aristotle himself or Aquinas himself would have endorsed a notion of "rights" resembling anything like the notion of "rights" that prevails in our contemporary context. One of the great contemporary representatives of the Aristotelian-Thomistic tradition in ethics and politics - Alasdair MacIntyre - holds that the notion of "natural rights" or "human rights" is alien to the thought of Aristotle and Aquinas. ${ }^{8}$ By contrast, many other thinkers working within the Aristotelian-Thomistic tradition have held that belief in human nature and human dignity entails belief in the existence of "natural rights" or "human rights." In this paper, I shall not directly address the question of what Aristotle himself or Aquinas himself might have said regarding the notion of the rights (especially the notion of "natural rights" or "human rights") as that notion is understood and discussed in our contemporary context. Instead, I shall aim to address a somewhat different question: whether an Aristotelian-Thomistic notion of "natural rights," broadly construed, can be made credible in our contemporary context.

First and foremost in the present enquiry, it is important to note that within an Aristotelian-Thomistic context, the notion of rights (including the notion of "natural rights" and "human rights") can have no defensible meaning apart from the notion of justice. In turn, the notion of justice can have no defensible meaning apart from the notion of a community of two or more members whose acts or works can be regarded as adjusted or commensurated to one another in some relevant respect (i.e., whose acts or works can be regarded as instantiating a kind of equality in some relevant respect and in accordance with some common measure). As Aristotle notes, it is generally accepted that injustice involves some sort of inequality, and justice involves some sort of equality. ${ }^{9}$ And as Aquinas observes, the proper object of justice is jus, or right, which is a kind of ordering or adjustment according to which the acts and/or works of separate individuals are made commensurate or equal with respect to one another. ${ }^{10}$

One immediate implication of the Aristotelian-Thomistic account of "right" is that "rights" are inescapably relational. To "possess a right," on the Aristotelian-Thomistic account I wish to explicate, is not to possess a power or liberty or natural property (such as the property of being bipedal, or having earlobes or kneecaps) that one would possess apart from any relation to others. Rather, to "possess a right" is to occupy a place within an order or ordering of

See Alasdair Maclntyre, After Virtue: A Study in Moral Theory. Notre Dame (IN) 1981. pp. 64-67.

See Aristotle, Nicomachean Ethics, Book V, chapter 3: see also Aristotle. Politics. Book III. chapter 12.

if See Thomas Aquinas, Summa theologica, II-II, Q. 57. aa. 1-3. 
justice, according to which two or more individuals are related to one another as equals in some relevant respect. But while on the Aristotelian-Thomistic account rights are relational, it does not follow that "respect for rights" is reducible to respect for values or goods that are "merely relative" or "merely convention-based." On the Aristotelian-Thomistic account, it is possible to regard human acts and works as commensurable to one another, only because such acts and works are expressions of a common human nature (and this human nature, in itself, entails a natural and species-specific capacity for rationality). If the proper commensuration between human individuals and their acts is observed, then (natural or positive) rights are respected; if the proper commensuration is not observed, then (natural or positive) rights are violated. But one should not lose sight of the fact that rights - which must be understood in connection with justice - are necessarily relational: to say that a certain kind of goodness or worthiness exists wherever human nature exists, is not to say that "natural rights" or "human rights" exist wherever some human being exists. To say that rights are inescapably relational is simply to say that rights can exist only where two ore more individuals can be treated as equals in some relevant respect (after all, if two or more individuals are to be treated "as equals" in some relevant respect, then they have to be related to each other in some way). However, to affirm the relational character of rights is (in itself) to affirm nothing (either positively or negatively) about the meaning or ground of human value or dignity. And as we shall see later, to affirm that rights are necessarily relational does not entail - as some utilitarians hold - that it is sometimes morally permissible to violate rights or "trade them away" for the sake of some greater social utility.

In order to delve more deeply into the question of rights, we need a fuller account of what precisely is meant by justice; and for this, we turn to the work of Thomas Aquinas. At the very beginning of his treatise on justice, Aquinas observes that the proper object of justice (justitia) is "right" or "the right" (jus). ${ }^{11}$ This observation allows him to point out that justice is unique among the virtues in at least two important respects: first, the proper end of justice (unlike the ends of the other virtues) is to direct the human being in his or her relations with others; and secondly, the works of justice (unlike the works of the other virtues) can be regarded as just, regardless of the manner in which the agent brings them about. These two unique features of justice are grounded in the fact that the proper object of justice (which is jus or "the right") pertains to an objective proportion or objective relation between individuals, and does not pertain intrinsically or necessarily to the passions or feelings of individuals said to be engaged in justice. Aquinas's observation about these two unique features of justice is worth quoting at length:

1 Thomas Aquinas, Summa theologica, II-II, Q. 57, a. 1. 
It is proper to justice, as compared with the other virtues, to direct man in his relations with others: because it denotes a kind of equality, as its very name implies; indeed we are wont to say that things are adjusted when they are made equal, for equality is in reference of one thing to some other. On the other hand, the other virtues perfect man in those matters only which befit him in relation to himself. Accordingly, that which is right in the works of other virtues, and to which the intention of the virtue tends as to its proper object, depends on its relation to the agent only, whereas the right in a work of justice, besides its relation to the agent, is set up by its relation to others. For a man's work is said to be just when it is related to some other by way of some kind of equality, for instance the payment of the wage due for a service rendered. And so a thing is said to be just, as having the rectitude of justice, when it is the term of an act of justice, without taking into account the way in which it is done by the agent: whereas in the other virtues, nothing is declared to be right unless it is done in a certain way by the agent. ${ }^{12}$

For Aquinas, then, the actualization or realization of the object of justice depends on external actions alone, and thus does not depend on the agent's will or reasons in bringing about such external actions. But it does not follow that the performance of an act of justice, properly understood, can be independent of the reasons or will behind such external actions. To explain this further, we need to distinguish - as Aquinas does - between: (a) the act or operation of justice; (b) the object of justice; and (c) the habit of justice. Aquinas draws these distinctions in his discussion of whether a person is properly called unjust on account of his or her activity in bringing about an unjust thing. Again, it is worthwhile to quote Aquinas at length on this point:

Even as the object of justice is something equal in external things (aliquid aequale in rebus exterioribus), so too the object of injustice is something unequal, through more or less being assigned to some person than is due to him. To this object the habit of injustice is compared by means of its proper act which is called an injustice. Accordingly, it may happen in two ways that a man who does an unjust thing, is not unjust: first, on account of a lack of correspondence between the operation and its proper object. For the operation takes its species and name from its direct and not from its indirect object: and in things directed to an end, the direct is that which is intended, and the indirect is what is beside the intention. Hence if a man do that which is unjust, without intending to do an unjust thing, for instance if he do it through ignorance, being unaware that it is unjust, properly speaking he does an unjust thing, not directly, but only indirectly, and, as it were, doing materially that which is unjust: hence such an operation is not called an injustice. Secondly, this may happen on account of a lack of proportion between the operation and the habit. For an injustice may sometimes arise from a passion, for instance,

12 Thomas Aquinas, Summa theologica, II-II, Q. 57, a. 1. 
anger or desire, and sometimes from choice, for instance, when the injustice itself is the direct object of one's complacency. In the latter case, properly speaking, it arises from a habit, because whenever a man has a habit, whatever befits that habit is, of itself, pleasant to him. Accordingly, to do what is unjust intentionally and by choice is proper to the unjust man, in which sense the unjust man is one who has the habit of injustice: but a man may do what is unjust, unintentionally or through passion, without having the habit of injustice. ${ }^{13}$

Following Aquinas's distinctions, we can say that: (a) the object of justice is right, which is some sort of objective equality, or something equal in exterior things (aliquid aequale in rebus exterioribus); (b) an act or operation of justice is a voluntarily willed act or operation which has as its direct (intended) object some sort of equality or proportionality in external things; and (c) the habit of justice is a fixed disposition involving a constant and perpetual will to render to each what is due to him or her as a matter of right (jus). What is implied by these distinctions is that an individual can act so as to bring about an unjust thing (aliquid inaequale in rebus exterioribus) even though that act is itself not an act of injustice; and similarly, an individual can act so as to bring about an unjust thing, even though the person is not an unjust person (which is to say that the person does not have the habit of injustice). Conversely, we can say that an individual can act so as to bring about a just thing (aliquid aequale in rebus exterioribus), even though the act is itself not an act of justice. For just as the act of injustice (strictly speaking) presupposes the voluntary willing of some objective inequality in external things as the agent's direct (intended) object, so too an act of justice (strictly speaking) presupposes the voluntary willing of some objective equality or proportionality in external things as the agent's direct (intended) object. What this account implies is that an act of justice (strictly speaking) includes - as the agent's own (intended) direct object some kind of properly proportioned ordering of relations among individuals that we might call a "system of justice" or "circle of justice." Within such a system or circle of justice, individuals may of course pursue what they perceive to be their own goods, but strictly speaking they engage in acts or operations of justice only insofar as they intend not only what is good for them, but also what is good for some other individual or individuals, precisely insofar as what is good for this other or these others is part of a system of justice, or a right ordering of relations among two or more individuals.

Now the other individual or individuals whose good the agent must intend through the act of justice, might be understood (a) as an individual who stands in relation to others as one part is related to some other part, or (b) as an individual who stands in relation to others as one part is related to a whole of which it is a part. In the former case (where the individual is understood as existing within a part-to-part relation), the kind of justice at issue is what we call

13 Thomas Aquinas, Summa theologica, II-II, Q. 59, a. 2. 
"commutative justice"; in the latter case (where the individual is understood as existing within a part-to-whole relation), the kind of justice at issue is what we call "distributive justice." 14 Now in both kinds of justice, an individual who engages in the act or operation of justice is one who intends (even in the midst of intending what is apprehended as good for himself or herself) that which is good for others insofar as what is good for others is an ingredient in a rightly ordered set of relations among individuals that we call a system or circle of justice. In performing the act or operation of distributive justice, an individual aims at promoting a set of relations involving what is good for some whole or community, and what is good for individuals within that community, precisely insofar as these different goods are rightly proportioned to one another in a system or circle of justice. Similarly, in performing the act or operation of commutative justice, an individual aims at promoting a set of relations involving what is good for one individual and what is good for some other individual, precisely insofar as these different goods are rightly proportioned to one another in a system or circle of justice. It should be noted, of course, that "individual" here - and throughout this paper - can also mean "individual group."

Here it is worthwhile to call attention to the subtle, but important, conceptual distinction between a "community" and a "circle of justice." On the Aristotelian-Thomistic account being presented here, a "community" pertains to a set of individuals that are ordered to some common end and thereby ordered in relation to one another in accordance with some common organizing principle or principles. By contrast, a "circle of justice" pertains to the set of relations that obtains between individual members of a community such that equals can be treated as equals in some relevant respect (i.e., such that justice can be done and rights can be respected within that community). While there can exist no "circle of justice" if there does not exist some appropriately constituted community to underwrite that circle of justice, there can however exist communities that do not automatically entail a corresponding and co-extensive circle of justice. Consider, for example, the traditional family unit, which is a community of a certain kind, but which does not by itself entail the existence of a "circle of justice" that is co-extensive with it. While relations of justice may exist between the two parents in the family unit, there can - strictly speaking be no such relations of justice obtaining between the parents and children; hence the circle of justice (or the set of relations involving justice) that characterizes the family unit does not fully coincide, or is not fully co-extensive, with the community that is the family unit. This is because justice is possible only where members of a community are related to one another as separate individuals (that is, as individuals capable of undertaking action on their own behalf); but as Aquinas points out, the actions of the child are not really the

if Thomas Aquinas, Summa theologica, II-II, Q. 61, a. 1. 
child's own (separate) actions since they fall under the direction and control of the parents. ${ }^{15}$ While parents and children within a family unit are bound together as members of a single community, they are not - by virtue of the family unit itself - bound together through relations of justice, or in a circle of justice.

\section{The Meaning of Rights}

According to the Aristotelian-Thomistic account being presented here, it is possible for individuals to be related to one another in a wide variety of ways, and to be capable of doing justice or injustice to one another in a wide variety of ways, depending on whether they share membership in one or another kind of community and circle of justice. But the crucial thing to note here is that it is only on the basis of some common membership in a community which underwrites a circle of justice that one can talk meaningfully about duties of justice owed and duties of justice violated, and thus about rights possessed and rights violated. For on the account being articulated here, to say that an individual has a duty of justice is to say that that individual ought to treat some other individual on terms that are equal, in some relevant respect, to the terms under which other individuals within that circle of justice are treated; and to say that an individual has a right is to say that that the individual ought to be treated on terms that are equal, in some relevant respect, to the terms under which other individuals within that circle of justice are treated. Note that the existence of duties and rights within a particular circle of justice does not require equal treatment in every respect, but only equal treatment in some respect that is relevant to the way that members relate to one another and relate to the community as a whole, precisely as members of that community and circle of justice. For example, equal treatment of employees within a particular manufacturing firm may require the payment of equal wages for equal work done (where such "equal treatment" may even incorporate a policy giving differential benefits - available equally to all employees - based on the employee's level of education, productivity, seniority within the firm, etc.). But equal treatment within this manufacturing firm would not require equal treatment in some respect that is irrelevant to the aim of the firm and the tasks of the individual employees (e.g., equal treatment here would not require the payment of equal wages to employees who are equally tall or equally goodlooking). Here equal treatment always means equal treatment in some relevant respect, given the proper nature and goals of the community that underwrites

15 Thomas Aquinas, Summa theologica, II-II, Q. 57, a. 4. 
the circle of justice and gives individuals the rights and duties that they have in relation to one another. ${ }^{16}$

It is possible, of course, to think of different individuals as being related to each other in a wide variety of ways, and within the context of various communities and circles of justice that give such individuals a variety of rights and duties with respect to one another. Thus, for example, an individual may have rights and duties with respect to others, by virtue of his or her membership in a particular family, or labor union, or social club. Within the traditional family, the rights and duties of justice between spouses would pertain to matters such as marital fidelity and access to the family's financial assets; within the labor union or social club, the rights and duties of justice might pertain to matters such as the payment of dues, attendance at meetings, eligibility to vote in elections, and eligibility to hold office.

Now two different communities - such as a labor union and a social club may happen to have some members in common (in which case there is some overlapping membership); or they may have no members in common (in which case there is no overlapping membership). Where there is overlapping membership, those individuals who happen to share membership in two or more different circles of justice will have more than one set of rights and duties with respect to one another. For example, such individuals may owe it to each other (as members of the labor union) to attend the union's regular meetings; and they may owe it each other (as members of the social club) to take turns organizing monthly social events. ${ }^{17}$ When any individual members fails to render what is owed to others within the context of a particular community and circle of justice (e.g., when a member of the social club fails to do what is expected equally of every member and fails to organize a social event during the month that has been duly assigned to him or her), then there has been an injustice, and thus a violation of right or rights. It is important to keep in mind, however, that the different sets of rights and duties that individuals have by virtue of their overlapping membership in two or more different communities are conceptually distinct and independent of one another. This is because each of the different communities - insofar as they are distinct communities - has its own unity, purpose, and principles of organization; and furthermore, indi-

16 Thus Aristotle observes that if the goal of some common endeavor (and thus a community) is to make good music. then a rightly-ordered distribution of the best flutes would be made on the basis of each individual's flute-playing ability, and not on the basis of birth or good looks. Given the goal of making good music, those who are bad flute-players do not have a right (they are not to be given equal access) when it comes to getting the best flutes. Similarly, a rightly-ordered distribution of offices within the polis is to be made, not on the basis of irrelevant qualities such as tallness or swiftness of foot, but rather on the basis of those qualities that can contribute to the proper functioning of the polis as a whole. See Aristotle, Politics. Book III, chapter 12 .

It should be noted that the very same act or omission may simultaneously constitute a violation of commutative justice and a violation of distributive justice. 
viduals have rights and duties with respect to one another by virtue of belonging to a particular community that underwrites a particular circle of justice. Where there happens to be overlapping membership (such that individuals share two or more sets of rights and duties with respect to one another, by virtue of their belonging to two or more separate, distinct communities), then the different sets of rights and duties are only accidentally related to one another; that is to say, the different sets of rights and duties are not underwritten by a common purpose and they are not subordinated to a single, common organizing principle. Accordingly, rightful decision-making will avoid treating one set of rights and duties (grounded in one circle of justice) as if they were directly commensurable or fungible with another set of rights and duties (grounded in some other circle of justice). Indeed, the act of failing to distinguish appropriately between one set of rights and duties and another, accidentally-related set of rights and duties, may itself constitute an injustice (and hence a violation of right). There would be such an injustice if - for example an individual were to take advantage of an accidentally-overlapping membership by using his or her decision-making office within one community (e.g., the social club) in order to hand out favors and thereby influence the official actions of an individual or individuals within some other, distinct community (e.g., the labor union).

Just as two distinct circles of justice, underwritten by two distinct communities, might have a merely accidental relation to one another (even though there happens to be an overlapping membership shared by them), so also two distinct circles of justice may be relatable to one another in a non-accidental way, by virtue of their both being subordinated to the goals and organizing principles of some third, higher-order community (and corresponding circle of justice). For example, a labor union and social club may constitute two communities that are separate, distinct, and otherwise only accidentally related to one another, except for the fact that both exist and operate within the legal jurisdiction of a particular political community (such as a nation-state). In such a case, the actions undertaken by individual members of the labor union and social club can be seen as accidentally related to one another in one respect (i.e., insofar as the actions are apprehended only under the aspect of their being the actions of members of the labor union or social club), but as not accidentally related to one another in some other respect (i.e., insofar as the actions are apprehended under the aspect of their being the actions of legal subjects within the context of a political community). Insofar as the actions of the members of the labor union and social club are regarded precisely as the actions of members of a broader, overarching political community (with its own corresponding circle of justice), these actions can be regarded as non-accidentally related to one another and thus as capable of being rightly ordered (or not rightly ordered) with respect to one another.

Where the actions of the members of the labor union and social club are regarded as the actions of members of a single, overarching political commu- 
nity, rightful decision-making will not treat all the rights and duties possessed by members of the labor union and social club as altogether separate and distinct from one another. Indeed, the act of treating all the rights and duties of members of the labor union and social club as entirely separate and distinct from one another may itself constitute an injustice (and hence a violation of right). There would be such an injustice if -for example - a member of the labor union stole property from a member of the social club and the member of the social club were denied legal redress on the grounds that the member of the labor union was merely acting within the separate and distinct context of the labor union, which had commanded the act of theft. It is worth emphasizing here that the circle of justice which makes it possible for members of the labor union and members of the social club to have rights and duties with respect to one another, is not a circle of justice underwritten by the labor union or by the social club, but rather a circle of justice underwritten by a political community within which both the labor union and the social club exist and operate. Thus individual members of the labor union and social club will have rights and duties with respect to one another, not precisely as members of the labor union or as members of the social club, but rather as members belonging to a single, overarching political community which - on the basis of its own goals and organizing principles - specifies an appropriate set of legal rights and duties for its members.

Furthermore, if the activities of certain lower-order communities (e.g., a labor union and a social club) are subordinated to the goals and organizing principles of some higher-order community (e.g., a political community), there may not only be certain instances in which the rights and duties of members of the lower-order communities are non-accidentally related to one another; there may also be instances in which the goals and organizing principles of the lower-order communities may rightly be guided or altered by the duly authorized officers of the higher-order community. If, for example, the leaders of the labor union were to command that their members commit acts of theft against members of the social club, then it would be legitimate for officers of the political community to command members of the labor union to disobey, or perhaps change, their union's leadership. Superficially, it might appear that this sort of command (being issued by officers of the political community) would involve a kind of "interference with" or "curtailment of" the labor union's "right of self-governance." But to think in terms of "interference" or "intervention" would be to make a category mistake. If the labor union exists and operates as a labor union only within the legal context of a political community, then - strictly speaking - there can be rightful (i.e., rightly-ordered) acts undertaken by the labor union only if such acts are consistent with and subordinated to the overarching (legal) framework of the political community. If the labor union (or its leadership) acts in a way that violates the political community's legal rules, then such acts are not rightful but instead fall outside the scope of the labor union's "right of self-governance." Accordingly, it is a 
category mistake to think that the rightful legal directives issued by the political community can involve any kind of "interference with" or "curtailment of" the labor union's "right of self-governance." Rather, the labor union's "right of self-governance" can be said to exist in the first place, only if it is a restricted right (i.e., only if it is subordinated to the legal rules of the political community). When the labor union undertakes activities falling outside the scope of its "right of self-governance," the political community's subsequent restriction on the labor union's activities is simply a restriction on illicit activities, and not a restriction on any existing rights. In other words, the "right of self-governance" possessed by the labor union can be said to have existence only within a legal context; when an act takes place outside of that legal context, it makes sense to say the act has existence outside of the legal context, but it makes no sense to say that the "right" to perform the act can have existence outside of the legal context - hence, the political community's interference with the labor union's (illicit) activities involves no interference with, or curtailment of, "rights." 18

The preceding account of how members of the labor union and the social club can be said to have rights and duties with respect to one another, provides us with a model for beginning to understand what it means for individuals to possess "natural rights" or "human rights." As indicated above, to "possess a right" is not to possess a power or liberty or natural property that one would possess apart from any relation to others. Rather, to "possess a right" is to occupy a place within a community that underwrites a circle of justice, according to which two or more individuals can be related to one another as equals in some relevant respect. One is said to possess "natural rights" or "human rights" if one belongs to a community that underwrites a circle of justice according to which equal treatment is due to individuals, based simply on the fact that such individuals belong to the same "natural class" or "natural kind," and thus share the same "human nature." When certain individuals are said to possess "natural rights" or "human rights," what is meant - strictly speaking is that equal treatment is due to such individuals on the grounds that these individuals have the same (equal) status simply as members of a certain kind of community which is the "natural class" or "natural kind" of which they are members. By contrast, when individuals are said to possess "positive" rights, what is meant is that equal treatment is due to such individuals, not strictly on the grounds that they share membership within a "natural class" or "natural kind," but rather on the grounds that they have the same (equal) status within the framework of a particular community (such as a labor union, social club,

18 In a similar vein, Aristotle says that a hand might seem to be capable of existing apart from a living body; but to think in this way is to make a category mistake. Strictly speaking, a hand by which is meant a living hand, and not just the matter out of which a hand is made - can exist only within the context of a living body. See Aristotle, Politics, Book I, chapter 2. 
or political community) that has in some way been devised or "posited" by human inventiveness or convention. Thus even if two or more human beings share no common membership in any kind of "posited" community (and thus even if they have absolutely no "positive" rights with respect to one another), it is nevertheless possible for them to possess "natural rights" with respect to one another, insofar as they share membership in a single, overarching natural community (defined in terms of a "natural class" or "natural kind") which is distinct from all posited communities (such as labor unions, social clubs, and nation-states).

Where "natural rights" are said to exist, one might also talk about "natural duties" to avoid acting in ways that would violate such natural rights. But not every being that possesses natural rights by virtue of belonging to a natural community (e.g., the natural community defined by the natural kind, "human being") can be said also to possess "natural duties." Consider the following case: infants and small children might be said to possess "natural rights" simply by virtue of belonging to the community defined by the natural kind, "human being"; however, it does not automatically follow that infants and small children also possess "natural duties" to avoid acting in ways that would violate the "natural rights" of others. For while infants and small children possess a status that calls for equal treatment in a particular respect (that is, simply in respect of being the kind of being that they are), they have not yet developed the ability to undertake (rational, responsible) action on their own behalf. As a result, they have not yet developed the ability to participate fully within a circle of justice and thus be possessors of duties as well as rights. Recall our earlier distinction between a "community" and a "circle of justice": a "community" pertains to a set of individuals that are ordered to some common end and thereby ordered in relation to one another in accordance with some common organizing principle or principles. A "circle of justice" pertains to the set of relations that obtains between individual members of a community such that equals can be treated as equals in some relevant respect (i.e., such that justice can be done and rights can be respected within that community). Infants and small children may be equal to all other members of a particular community (and thus equally possessors of human rights) simply insofar as they are beings of a certain kind; however, it does not follow that they are equal to all members of the community in every respect, such as in respect of their ability to undertake (rational, responsible) action on their own behalf (and thus be possessors of duties). The point can be made in a slightly different way: recall that justice, strictly speaking, is possible only where members of a community are related to one another as separate individuals. Infants and small children can be regarded as separate individuals simply insofar as they have separate existence as individuals belonging to certain kind of natural class or kind; but it does not follow that they have separate existence as individuals who exercise their own rational agency and decision-making abilities; for the actions of infants and small children are not really their own actions, but rather fall under 
the direction and control of others. Thus even if infants and small children may possess "natural rights," it does not follow that they automatically possess corresponding "natural duties."

It is worth emphasizing here that, on the Aristotelian-Thomistic account being presented, it remains the case that "natural rights" and "human rights" are inescapably relational. But it does not follow that respect for "natural rights" or "human rights" is reducible to respect for values or goods that are "merely relative" or "merely convention-based." While "rights" are inescapably relational (insofar as the very notion of rights pertains to "equal treatment" of two or more individuals in some relevant respect), it remains the case that the very foundation of "natural rights" or "human rights" (namely, membership in a community defined by a natural kind) is not "merely relative" or "merely convention-based." The crucial point might be illustrated through an analogy drawn from the physical sciences: the notion of "natural rights" stands to the notion of "human nature" as the notion of "weight" stands to the notion of "mass." According to the modern scientific understanding, a body does not have weight if there is no other body present to exert the gravitational force of attraction upon it; but while a body has weight only insofar as it stands in relation to some other body, a body is capable of having such weight only because it is a body which by its very nature has mass, and would continue to have mass even if it did not stand in relation to any other body. By the same token, a human being does not possess "natural rights" if his or her acts or works cannot be regarded as adjustable or commensurable to the acts or works of other human beings; but while a human being has "natural rights" only insofar as he or she stands in some relevant relation to one or more other human beings, a human being is capable of having such natural rights only because he or she by nature belongs to a certain natural (and not merely posited or socially-constructed) class of things, and therefore possesses what we call "human nature"; and furthermore, the human being would continue to possess this human nature (and would continue to possess all the value or dignity that properly belongs to beings of this nature), even if he or she did not stand in relation to any other human beings.

\section{The Relevance of Double Effect}

It was noted above (in Section II, on the meaning of justice) that if the proper equality between individuals (and/or their acts) is observed, then (natural or positive) rights are respected; and if the proper equality is not observed, then (natural or positive) rights are violated. We are now in a position to begin understanding why rights are said to be "inviolable." On the AristotelianThomistic account being presented here, every right - strictly speaking - is inviolable since every act or operation of injustice (i.e., every human act that has 
as its intended object some lack of proper equality between individuals) is contrary to right reason and thus morally illicit. Stated in terms that are often used in our contemporary context, every act or operation of injustice is "intrinsically evil," which - it should be emphasized - is not to say that every act or operation of injustice is extremely evil. To say that every act or operation of injustice is intrinsically evil is simply to say that there is no description of the act or operation according to which the act might be morally licit or permissible. As is the case with acts of adultery and stealing, the act or operation of injustice - by its very nature or definition - is morally impermissible; it is not possible to perform an act of adultery, stealing, or injustice in a morally correct way. Now to the extent that every act or operation of injustice is morally illicit, it is also the case that every right is inviolable - which is just another way of saying that there is an absolute or unconditional moral prohibition against violating anyone's rights. Of course, it is also the case that some rights-violations can be more egregious than other rights-violations, which is to say that the goods that might be harmed as a result of certain rightsviolations are greater goods than those that might be harmed as a result of other rights-violations. Thus, while every act of injustice is morally illicit, the good that is harmed in the unjust taking of another person's life is a much greater good than the good that is harmed in the unjust destruction of another person's property.

Let us now return to Aquinas's important distinction between the act of injustice (i.e., the voluntarily willed act whose direct aim or end is to bring about some lack of proper equality between individuals) and the object of injustice (i.e., the objective state affairs involving a lack of proper equality between individuals). For Aquinas, it is possible for human beings to act in ways that bring about unfitting inequalities between individuals, even if no human being engages (intentionally) in acts or operations of injustice. This is because - as Aquinas points out - not all human actions are of the same kind. ${ }^{19}$ Human beings may act in ways that bring about unfitting inequalities between individuals, yet without having knowledge of or control over the conditions that constitute such inequalities. In such cases, humans may play a causal role in the coming to be of unfitting inequalities between individuals, but their causal role would involve no voluntariness and thus no moral culpability. Imagine a situation in which a local government decides to excavate a certain piece of land in order to build a dam and thereby protect the citizens against almost-certain flooding; now imagine that the excavation stirs up a colony of influenzacarrying insects that eventually move into residential areas, infect thousands of citizens, and cause hundreds of flu-related deaths among those who happen to live closest to the excavation site. If the local government officials acted in non-culpable ignorance of such possible risks and consequences, then -

19 See Thomas Aquinas, Summa theologica, I-II, Q., 6 and Q. 12. 
strictly speaking - their role in bringing about the unfitting inequality between individuals (i.e., the inequality reflected in the fact that hundreds of people lost their lives simply because they happened to live close to the excavation site) involves no voluntariness and no moral culpability; strictly speaking, there has been no act of injustice, and no violation of rights.

Now in addition, human agents may act in ways that bring about unfitting inequality between individuals, where the causing of the unfitting inequality between individuals falls within the scope of what the agent can predict and control, but nevertheless outside the scope of what the agent desires and intends to bring about. In such a case, the agent's act of bringing about a particular state of affairs is said to be voluntary, but not intentional. Notice here that intentional actions form a sub-set within a larger set of voluntary actions: an agent intentionally brings about some state of affairs, $X$, when the agent not only acts voluntarily (i.e., with knowledge and some degree of control over the coming to be of $X$ ), but also acts out of the desire to bring about X, insofar as $X$ is deemed by the agent as being good ("good" either as an end in itself, or "good" as a means to some further end that the agent desires). According to Aquinas, an act of injustice - strictly speaking - is an intended act (e.g., an act whereby one engages in theft and thus aims to bring about some sort of inequality or lack of proportionality between individuals). While it is never morally permissible to perform an act of injustice, there is no similar absolute moral prohibition against acts that involve the voluntary, but unintended, bringing about of unfitting inequalities between individuals. This ethical position lies very close to the heart of the Thomistic doctrine of "double effect." According to that doctrine, it is never morally permissible (i.e., it is intrinsically evil) to engage in an act or operation of injustice (where the unfitting inequality between individuals is intended, as in the case of theft); but whether or not it is morally permissible to bring about an unfitting inequality between individuals as a matter of merely voluntary action (where the inequality falls outside the scope of what the agent intends, but within the scope of what the agent is able to know and control) will depend on a variety of further circumstances (and not on the nature of the act alone).

To borrow from a hypothetical scenario made famous by Philippa Foot ${ }^{21}$ and Judith Jarvis Thomson ${ }^{22}$ : it is never morally permissible for an individual to drive a trolley over an innocent human being, where the individual's direct (intended and desired) object is to kill the other human being. But it may be

20 See, for example, Thomas Aquinas, Summa theologica, II-II, Q. 64, a. 7. See also G. Elizabeth M. Anscombe, Action, Intention, and 'Double Effect,' in: Proceedings of the American Catholic Philosophical Association, Washington D. C. 1982, pp. 12-25.

21 See Philippa Foot, The Problem of Abortion and the Doctrine of Double Effect, in: Virtues and Vices: And Other Essays in Moral Philosophy, Berkeley 1978, pp. 19-32.

22 See Judith Jarvis Thomson, The Trolley Problem, in: The Yale Law Journal, Vol. 94, no. 6 (May 1985). pp. 1395-1415. 
morally permissible for an individual to drive a trolley over an innocent human being, where the individual's direct (intended and desired) object is not to kill the other human being, but rather to save the lives of five other human beings by redirecting the trolley away from one track (where five human beings are standing) and onto a second track (where the one human being is standing). Even though the trolley driver may fully foresee that one human being will be killed as a result of the driver's own action in saving the lives of five others, the fact remains that the killing of the one is not intended - either as an end in itself, or even as a means to saving the lives of five other human beings. The fact that the killing of the one is not intended even as a means to the saving of the five, is illustrated by this counter-factual: the trolley driver would still have good reason (i.e., would still desire and intend) to direct the trolley away from one track (where the five are standing) and onto a second track (where the one is standing), even if the second track was empty and did not have the one human being standing on it. It is only the directing of the trolley away from the five - and not the killing of the one - that falls within the scope of the trolley driver's intention (however, the killing of the one still remains within the scope of the trolley driver's voluntary action).

Now the doctrine of double effect - as illustrated through the hypothetical example of the trolley - may help to illuminate the issue of mandatory influenza vaccines, raised at the beginning of this paper. On the AristotelianThomistic account of rights and justice being presented here, it would never be morally permissible - thus it would be intrinsically evil and a violation of rights - if a local government were to engage in any action that had as its intended object some kind of unfitting inequality between individuals. For example, it would be a violation of (positive) rights if the local government were to act intentionally to seize and destroy the private property of a randomlychosen group of unlucky citizens; and it would be a violation of (natural) rights if the local government were to act intentionally to inject a deadly influenza virus into the bodies of a randomly-chosen group of unlucky citizens. Incidentally, the government's intentional act of injecting citizens with the influenza virus would constitute an injustice (and thus a violation of rights) precisely insofar as the action would involve the unequal treatment of individuals who ought to be treated equally. But this very same act (of injecting citizens with the influenza virus) could remain a wrongful act, even if (under certain circumstances) it could no longer be characterized as an unjust act or a violation of rights. Consider: if only one citizen were intentionally injected with the influenza virus and if - per impossibile - there existed no other human beings in relation to which this one human being could be said to have been given unequal treatment, it would not longer be accurate to describe the act as an unjust act or a violation of rights; nevertheless, it would still be accurate to describe it as a wrongful act (it would be wrongful insofar as it was an act that failed to preserve and protect the goodness and dignity that belong to every 
human being, simply on the grounds of membership within a certain natural kind or class of things).

Let us return now to the scenario in which the act of exposing certain individuals to a potentially deadly influenza virus is a voluntary act, but not an intentional act. If a local government refrains from passing laws that require influenza vaccinations for all at-risk populations, then is it right to say that a culpable wrong has occurred, when and if a non-immunized citizen eventually dies of influenza-related causes? The answer to this question will depend on a wide variety of further facts and circumstances. Could the local government have mandated the influenza vaccinations while at the same time securing without loss or diminishment - the many other goods that the government is responsible for delivering to its citizens? Would mandated influenza vaccinations have entailed the forfeiture other, compelling goods (e.g. the good of allowing citizens to make certain decisions on their own, or the good of preserving the integrity of the law by steering clear of legal mandates that may well become too intrusive and too difficult to enforce)? Aquinas points out that there can be voluntariness - and thus moral culpability - even in instances where an agent opts to refrain from acting. Culpability in such instances would arise when an agent ought to have acted in a certain way, but chose instead to act in a different way, or chose not to act at all. ${ }^{23}$ The fact remains that a local government's act of refraining from mandating influenza vaccinations (provided that it is not an action undertaken with the intention of exposing citizens to a potentially deadly influenza virus) is an act that is neither rightful or wrongful on its own terms. And when an act is neither intrinsically evil nor intrinsically benign, there is a great deal of room left for the empirical calculations that rightly belong to sound prudential reasoning.

\section{References}

Anscombe, G. Elizabeth M., Action, Intention, and 'Double Effect,' in: Proceedings of the American Catholic Philosophical Association, Washington D. C.: American Catholic Philosophical Association 1982.

Aristotle, Politics, New York: Oxford University Press 1995.

Dworkin, Ronald, Taking Rights Seriously, Cambridge (MA): Harvard University Press 1977.

Dworkin, Ronald, Rights as Trumps, in: Theories of Rights, edited by Jeremy Waldron. Oxford: Oxford University Press 1984, pp. 153-168.

Foot, Philippa, The Problem of Abortion and the Doctrine of Double Effect, in: Virtues and Vices: And Other Essays in Moral Philosophy, Berkeley: University of California Press 1978.

See Thomas Aquinas, Summa theologica, I-II, Q. 6, a. 3, and Q. 71, a. 5. 
MacIntyre, Alasdair, After Virtue: A Study in Moral Theory, Notre Dame (IN): University of Notre Dame Press, 1981.

Maritain, Jacques, Man and the State, Chicago: University of Chicago Press 1951.

Singer, Peter, A Response to Martha Nussbaum, online <http://www.utilitarian.net/ singer/by/20021113.htm>.

Thomas Aquinas, The Summa Theologica of St. Thomas Aquinas, translated by the Fathers of the Dominican Provinc, New York: Benziger Bros. 1948.

Thomson, Judith Jarvis, The Trolley Problem, in: The Yale Law Journal, Vol. 94, no. 6 (May 1985), pp. 1395-1415. 